\title{
A new approach to estimate armourstone abrasion: modified slake durability test
}

\author{
Ö. Acır \& R. Kılıç \\ Ankara University, Department of Geological Engineering, Turkey
}

\begin{abstract}
Since armourstones are located in the outer shelter layer of breakwaters which absorb the first impact of hydraulic wave energy, they are prone to the highest degree of abrasion. Sea and atmospheric conditions damage the armourstone integrity so they lose their engineering functions in time. Existing classification systems to investigate the potential armourstone durability are performed on the intact rocks obtained from stone quarries; hence they do not explain the abrasion mechanism of armourstones actually used in the breakwater. For this reason, the standard slake durability test method was modified based on physical modelling techniques so that armourstone abrasion was simulated in realistic conditions. Eastern Black sea water and basaltic armourstones of the Giresun port were used in model tests. The model tests reveal that abrasion is inversely proportional to the mass and dimension of the armourstone.
\end{abstract}

Keywords: Eastern Black sea, armourstone, modelling, modified slake durability.

\section{Introduction}

The term "modelling" is simply used for describing the investigation of events and processes under a certain scale. Meanwhile, modelling in engineering geology is generally referred to the studies performed to investigate either strong ground motion (Krawnikler [15], Harris and Sabnis [9]) or mechanical behaviour of geomaterials (Wood [20]).

Physical models, re-sized prototypes of engineering structures scaled by Froude's Law, are the basic elements of modelling approach (Hughes [11]). Physical models are widely used to simulate the realistic effects of coastal processes on the structure to perform damage analysis in a hydraulic laboratory 
environment (Hudson [10] and Van der Meer [21]), such as storms, ebbs and tides, and tsunamis (Yüksel et al. [22]). On the other hand, there exist various case studies about damaged coastal structures due to the absence or insufficient modelling analysis during the design period (Kapdaşlı [13]). Current modelling applications in coastal engineering merely deal with the overall structural damage, not with the single element, like armourstones (Melby [17]). Standard rock mechanic tests are used to estimate the potential durability of armourstones (CIRIA/CUR [2]) such as Los Angeles abrasion, methylene blue, magnesium sulphate soundness, wet-dry loss and free-thaw loss etc. However, they do not represent the actual degradation degree of rocks used in marine environments, since the test specimen is never reacted with sea water in any of those tests. Inservice durability of armourstones is a still matter of discussion in geological and coastal engineering research (Latham et al. [16]).

\section{Slake durability test}

The slake durability test (Gamble [6], Franklin and Chandra [5] and ISRM [12]) was originally developed to determine the durability of weak rocks such as shale and mudstones. The test is performed in a steel drum which is submerged below $20 \mathrm{~mm}$ of water with rock samples, total $450-550 \mathrm{~g}$. The drum is rotated for 10 minutes and dried for 12 hours in the oven, where the rocks are degraded by hitting each other or the inner wall of the steel drum (Figure 1). The percent ratio of dry weight of the samples after second rotation to the original weight is known as the "Slake Durability Index, SDI". This test was developed in several

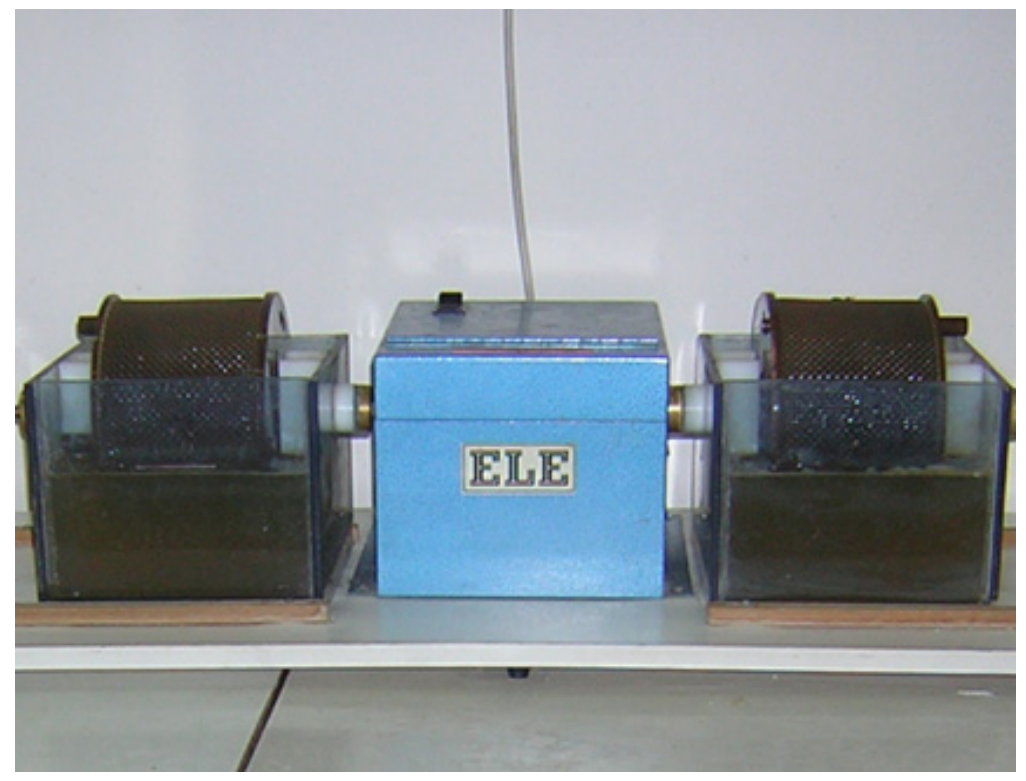

Figure 1: Slake durability test apparatus. 
ways by various researches as increasing the rotation period (Ulusay et al. [19] and Gökçeoğlu et al. [7]), using sea water (Dhakal et al. [4]), water with different pH degrees (Gupta and Ahmed [8]) or with specimens in various shapes (Kolay and Kayabalı [14]). None of these studies were performed to investigate armourstone durability specifically, although the slake durability test is designed to measure the rock abrasion in water.

\section{Modified slake durability test}

In rubblemound breakwaters, armourstones are selected from several weight classes, such as 2, 4, 6, 8 and 10 tons (CERC [3]). Those stones are exposed to coastal processes during their entire service life where sea water is the major abrasive agent. In coastal engineering models, port and breakwater structures are re-sized in a selected scale and exposed to 1000 and 5000 numbers of wave attacks accordingly, which are assumed to be the worst case scenarios in terms of structural damage (Thompson and Shutler [18], CERC [3], Van der Meer [21]).

The modified slake durability test is a developed form of the standard test method, based on above physical modelling techniques to estimate the abrasion degree of armourstones. During the modified test, 2 types of armourstones were used from the Giresun port's main breakwater (produced from "Kalearkası" and "Kovanlık" basalt quarries, Figure 2), representing 2, 4, 6, 8 and 10 tons each

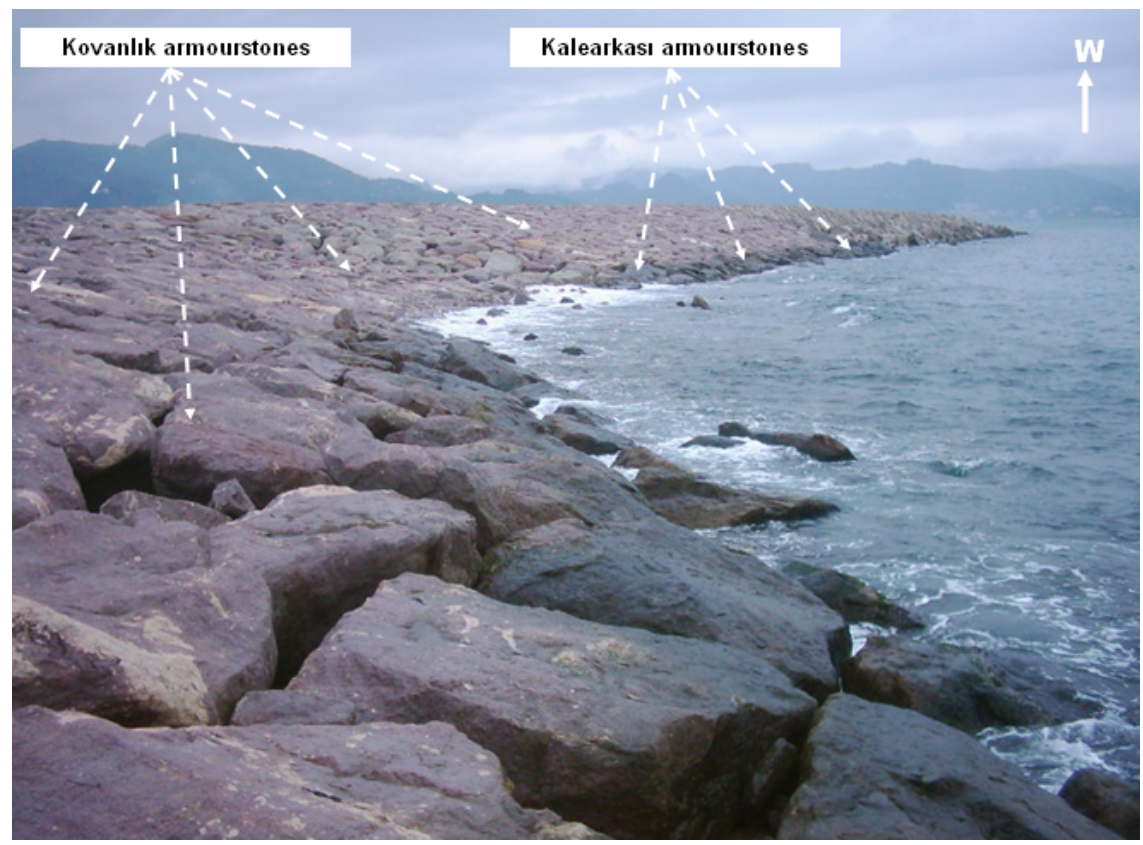

Figure 2: General view of the Giresun port's main breakwater and location of armourstones produced from Kovanlık and Kalearkası stone quarries. 
(Table 1). These materials were selected for model tests since they are good examples of armourstone abrasion along the Black Sea coastline (Acır and Kılıç [1]).

Samples were fixed in polymer nets having $25 \mathrm{~mm}$ spacing, to prevent either hitting each other or being smashed by the inner walls of the drum (Figure 3 ) and the only contact was with water. The duration of the test was also set up as

Table 1: Physical model weights of the armourstones by $1 / 30$ scale, which were used in the modified slake durability test.

\begin{tabular}{|c|c|c|}
\hline \multirow{2}{*}{ Armourstone weight (tons) } & \multicolumn{2}{|c|}{ Prototype physical models (g) } \\
\cline { 2 - 3 } & Kalearkas1 samples & Kovanlık samples \\
\hline 2 & 71,11 & 72,81 \\
\hline 4 & 155,20 & 144,06 \\
\hline 6 & 222,43 & 218,16 \\
\hline 8 & 286,42 & 296,57 \\
\hline 10 & 361,14 & 349,95 \\
\hline
\end{tabular}

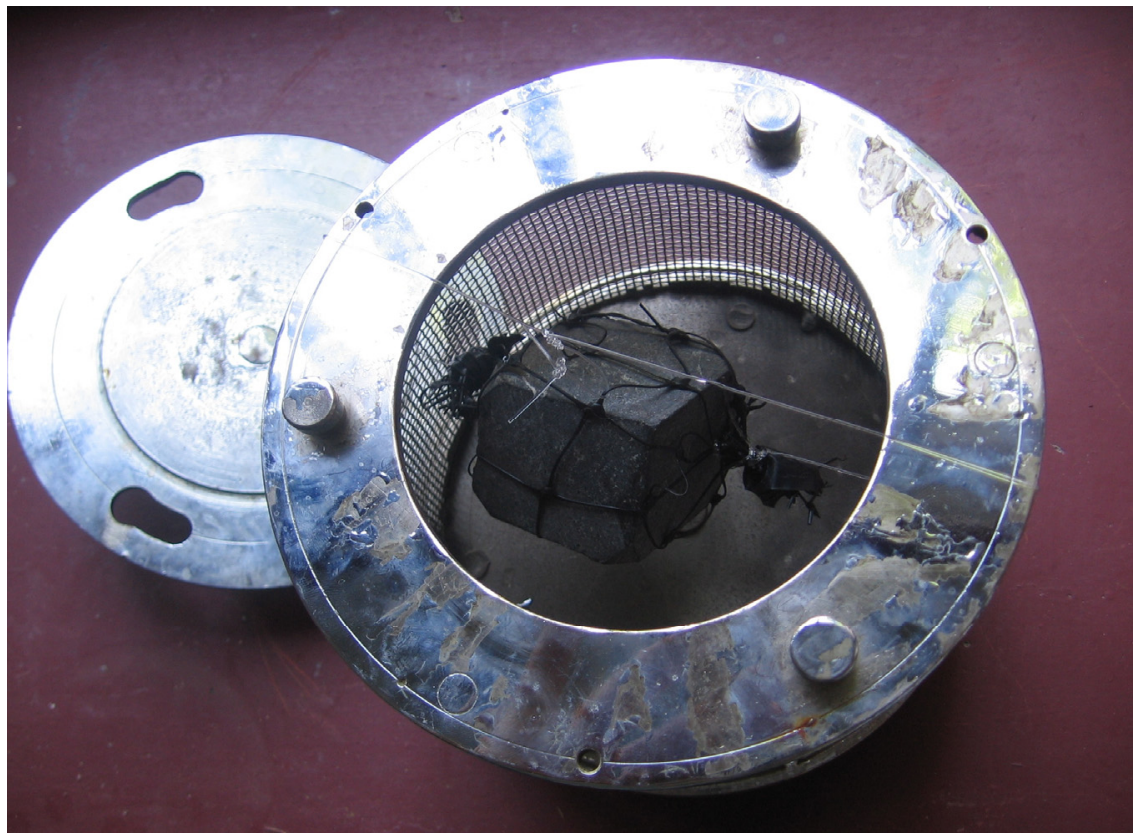

Figure 3: Modified slake durability test apparatus: Physical model is fixed by fishing line along the center of the drum and covered by a $25 \mathrm{~mm}$ hollowed polymer net. 


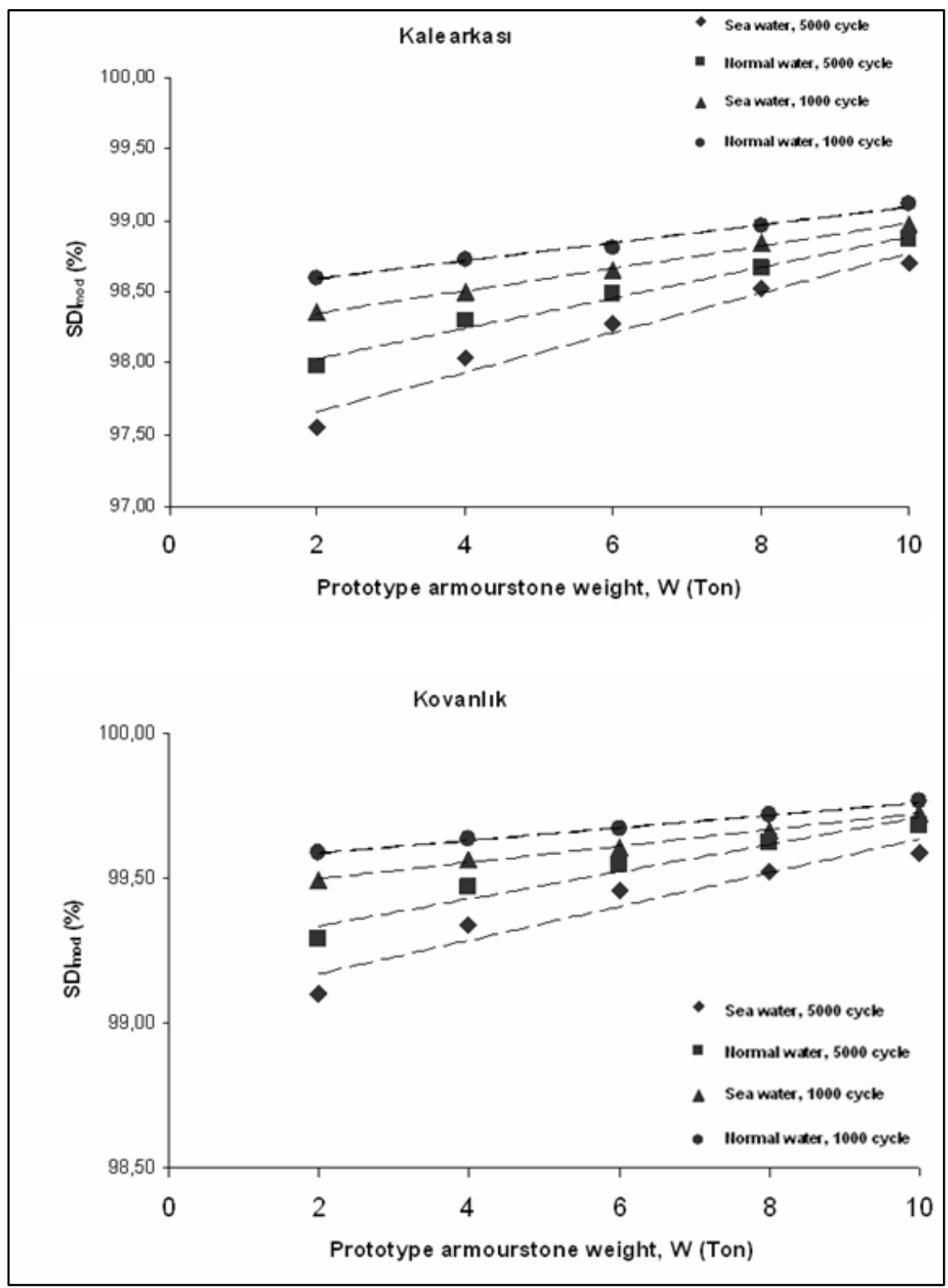

Figure 4: Relationship between the Modified Slake Durability Index ( $\mathrm{SDI}_{\mathrm{mod}}$ ) versus armourstone weight (W) for Kovanlı (a) and Kalearkası (b) armourstones. 
50 minutes (for 1000 ea waves) and 250 minutes (for 5000 ea waves) since standard rotation speed of the slake durability test is $20 \mathrm{rev} / \mathrm{min}$. In the modified slake durability test, it is assumed that each $360^{\circ}$ rotation of the drums create 1 ea sea wave which hits the armourstone's face. After each test, samples were dried in an oven at $105 \pm 5^{\circ} \mathrm{C}$ during 24 hours and the dry weight of the samples after the second rotation to the original weight was calculated, which is called the "Modified Slake Durability Index, SDI mod".

The salt concentration of sea water taken from the offshore side of Giresun port is $0.18 \%$ and the $\mathrm{pH}$ is 8,4 . Accordingly, the $\mathrm{pH}$ of the normal water used in standard tests is 7,35 . The modified slake durability test was performed with both sea and normal water to compare the armourstone reaction with water type and time.

\section{Test results}

Tests were conducted with 2 armourstone sources (Kalearkası and Kovanlık quarry basalts) and 5 sets of samples, 2 types of water (normal and sea water), 5 representing armourstone classes $(2,4,6,8$ and 10 tons) and 2 time periods (50 and 250 minutes). Therefore 200 ea test results were derived from the model experiments, which are shown in Figure 5 and Table 2.

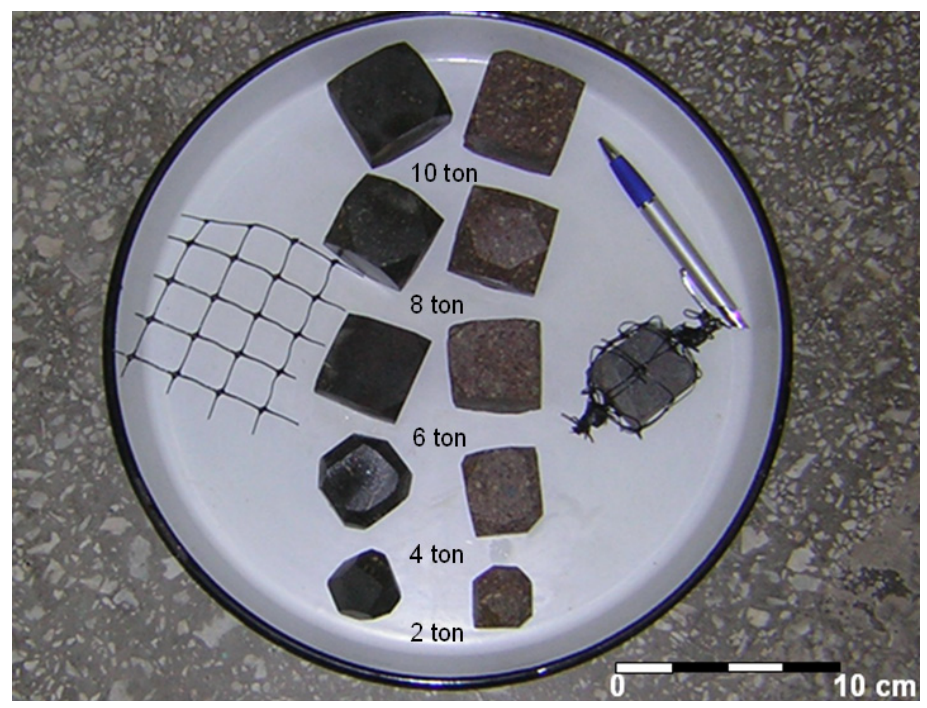

Figure 5: $\quad$ Prototoype armourstone models used in the experiments prepared by $1 / 30$ scale. 
Table 2: $\quad$ Equations derived from the experimental results.

\begin{tabular}{|c|c|c|c|c|}
\hline \multirow{2}{*}{$\begin{array}{l}\text { Model } \\
\text { experiments }\end{array}$} & \multicolumn{2}{|l|}{$\begin{array}{c}\text { Kalearkası } \\
\text { Armourstones }\end{array}$} & \multicolumn{2}{|l|}{$\begin{array}{c}\text { Kovanlık } \\
\text { Armourstones }\end{array}$} \\
\hline & Equation & $\mathbf{R}^{2}$ & Equation & $\mathbf{R}^{2}$ \\
\hline $\begin{array}{l}\text { Sea water, } \\
5000 \text { cycle }\end{array}$ & $\mathrm{SDI}_{\mathrm{mod}}=97,386 \mathrm{e}^{0,0014 \mathrm{~W}}$ & 0,95 & $\mathrm{SDI}_{\text {mod }}=99,054 \mathrm{e}^{0,0006 \mathrm{~W}}$ & 0,91 \\
\hline $\begin{array}{l}\text { Normal water, } \\
5000 \text { cycle }\end{array}$ & $\mathrm{SDI}_{\text {mod }}=97,818 \mathrm{e}^{0,0011 \mathrm{~W}}$ & 0,98 & $\mathrm{SDI}_{\text {mod }}=99,242 \mathrm{e}^{0,0005 \mathrm{~W}}$ & 0,95 \\
\hline $\begin{array}{l}\text { Sea water, } \\
1000 \text { cycle }\end{array}$ & $\mathrm{SDI}_{\bmod }=98,194 \mathrm{e}^{0,0008 \mathrm{~W}}$ & 0,99 & $\mathrm{SDI}_{\text {mod }}=99,443 \mathrm{e}^{0,0003 \mathrm{~W}}$ & 0,99 \\
\hline $\begin{array}{l}\text { Normal water, } \\
1000 \text { cycle }\end{array}$ & $\mathrm{SDI}_{\mathrm{mod}}=98,465 \mathrm{e}^{0,0006 \mathrm{~W}}$ & 0,99 & $\mathrm{SDI}_{\text {mod }}=99,544 \mathrm{e}^{0,0002 \mathrm{~W}}$ & 0,99 \\
\hline
\end{tabular}

\section{Conclusions}

Test results reveal that

- In both Kalearkası and Kovanlık armourstones, the highest abrasion occurs at 5000 rotation with sea water whereas the lowest abrasion occurs at 1000 rotation with normal water. This result indicates that sea water has a relatively higher effect on degradation of rocks with regards to the salinity and $\mathrm{pH}$ degree through time.

- Abrasion mechanism is inversely proportional to the armourstone weight. In other words, abrasion increases where the mass of armourstone decreases, vice versa. This result can be explained by the specific area of the rocks, which is the ratio of surface area to the mass. As the mass increases, specific area and the exposed area of rocks, which is prone to the sea water, decreases, relatively. Therefore, abrasion occurs at most in smaller masses.

- This test is developed by using basaltic rocks used in the same breakwater, therefore results can not be generalised. However, the methodology of this model is suitable to test various case studies with armourstones from different lithology and water chemistry from different seas.

\section{References}

[1] Acır, Ö. and Kılıç R., 2008, Investigation of the Quality and Durability of Armourstones Used in Giresun Port's Main Breakwater, XII ${ }^{\text {th }}$ Regional Rock Mechanics Symposium, İzmir, Turkey

[2] CIRIA/CUR 1991. "Manual on the use of rock in coastal and shoreline engineering" CIRIA special publication 83, CUR report 154, 607 pp. 
[3] CERC (Coastal Engineering Research Center) 1977, Shore Protection Manual, US Army Coastal Engineers Research Center, Fort Belvoir, VA.

[4] Dhakal G, Kodama J; Yoneda T, Neaupane M and Goto T, 2004, "Durability Characteristics of Some Assorted Rocks" Journal of Cold Regions Engineering, Vol. 18, No. 3, 110-122

[5] Franklin, J. A. and Chandra R., 1972, "The slake-durability test" International Journal of Rock Mechanics and Mining Science \& Geomechanics Abstracts, Volume 9, Issue 3, May 1972, pp 325-328

[6] Gamble, J.C, 1971, "Durability-plasticity Classification of Shales and Other Argillaceous Rocks", PhD Thesis, University of Illinois (unpublished)

[7] Gökçeoğlu, C., Ulusay, R., and Sönmez, H.,2000, "Factors affecting the durability of selected weak and clay-bearing rocks from Turkey with particular emphasis on the influence of the number of drying and wetting cycles" Engineering Geology, 57

[8] Gupta V. and Ahmed I., 2007 "The effect of $\mathrm{pH}$ of water and mineralogical properties on the slake durability (degradability) of different rocks from the Lesser Himalaya, India" Engineering Geology, Volume 95, Issues 3-4, 7, pp 79-87

[9] Harris, H.G., Sabnis, G.M., 1999, Structural modeling and experimental techniques ( $2^{\text {nd }}$ Edition), CRC Press, Boca Raton.

[10] Hudson, R.Y., 1959, "Laboratory Investigation of Rubble Mound Breakwaters" Journal of Waterway and Harbor Division ASCE, 85, 93121

[11] Hughes, S.A, 1993, "Physical Models and Laboratory Techniques in Coastal Engineering” World Scientific, Volume 7

[12] ISRM (International Society for Rock Mechanics), 1981, "Rock Characterization, Testing and Monitoring: ISRM Suggested Methods", E.T. Brown (ed), Pergamon Pres, 211 p.

[13] Kapdaşlı D., 1992, "Kıyı Mühendisliği”" İstanbul Teknik Üniversitesi Rektörlüğü, Yayın No:1504, s277 (In Turkish)

[14] Kolay, E. and Kayabalı. K., 2006, Investigation of the effect of aggregate shape and surface roughness on the slake durability index using the fractal dimension approach. Engineering Geology, (86) 4, 271-284

[15] Krawnikler, H., 1979, Possibilities and limitations of scale-model testing in earthquake engineering. Proc. 2nd US National Conf. on Earthquakes Engineering, Stanford University 283-292.

[16] Latham, J.P, Lienhart, D., Dupray S, 2006, "Rock quality, durability and service life prediction of armourstone", Engineering Geology 87, 122-140

[17] Melby J., 1999, Damage progression on rubble mound breakwaters, Technical report CHL-99-17, US Army Corps of Engineers

[18] Thompson, D.M., and Shutler R.M., 1976, Design of rip rap slope protection against wind waves, Report No: 61, CIRIA, London

[19] Ulusay, R, Arıkan F., Yoleri, M.F., and Çağlan, D., 1995, Engineering geological characterization of coal mine waste material and evaluation in 
the context of back-analysis of spoil pile instabilities in a strip mine, SW Turkey, Engineering Geology, 40, 77-101

[20] Wood. D, 2006, Geotechnical Modeling, ISBN: 0419237305, 488 p

[21] Van der Meer, 1988, Rock slopes and gravel beaches under wave attack, Delft Hydraulics Communication No:396, The Netherlands.

[22] Yüksel Y., Çecik E., Çelikoğlu Y., 1998, Kıyı ve Liman Mühendisliği, TMOBB İnşat Mühendisleri Odası Ankara Şubesi yayınları, Ankara, s 401 (In Turkish) 